\title{
Sedulius' Peter: Intention and Authority in the Paschale carmen
}

\author{
Carl P. E. Springer
}

Authorial intent is a notoriously difficult issue for interpreters of all texts in general and of ancient texts in particular. ${ }^{1}$ How can readers today get a clear sense of what an author may have wanted to say so long ago, writing in a language and inhabiting a world of thought so different from their own? Indeed, it is no easy matter even when one is studying the works of living authors who are writing in their readers' own languages, especially if they do not care to shed any particular light on their motivations to write, or offer deliberately misleading or inadequate explanations, or pursue their literary projects with a degree of real or feigned innocence. With these caveats in mind, I want to explore here a possible purpose which Sedulius may have intended his Latin biblical epic, the Paschale carmen, to serve for his contemporary readers. All too often, this poem has been approached as though it were written in a contextless vacuum, without any purpose or point and its author regarded as little more than a 'grandiloquent' rhetor who had 'a large measure of literary ambition', but 'nothing to say'.2 I assume instead that Sedulius may have had real, pressing reasons for writing his poem and suggest here that one of them was to "anchor" (to adopt the nautical imagery Sedulius himself uses in his second prefatory letter to Macedonius) his readers and himself more securely to the authoritative figure of the apostle Peter. ${ }^{3}$

Judicious use of biographical information can be helpful for those seeking to understand an author's background, education, and motivation, and need not necessarily lead us into the predictable trap of the "biographical fallacy," whereby a literary work is reduced to little more than a product of

1 See Farrell (2017). In his The Death of the Author, Roland Barthes provocatively suggested that authorial intentions or "origins" matter far less than a literary work's readerly "destination;" see Springer (2013) xlii.

2 Curtius (1973) 462. If contemporary Christological or ecclesiological issues are ignored by the modern reader, it is not surprising that this poem would be easily dismissed (as Curtius does) as a sort of overgrown paraphrastic exercise, filled with tired rhetorical topoi that have lost whatever relevance they might once have had.

3 Springer (2013) 218-21.

(C) CARL P.E. SPRINGER, 2020 | DOI:10.1163/9789004425682_011

This is an open access chapter distributed under the terms of the CC BY-NC 4.0 license. 
its circumstances. ${ }^{4}$ Of course, it is true that in comparison with the wealth of information we possess about most modern authors, we know far less about ancient authors in general and Sedulius in particular. But we can be fairly sure of one thing about Sedulius: some sort of edition of his works was produced by a Roman consul (Turcius Rufius Apronianus Asterius) who served in $494{ }^{5}$ This gives us a terminus ante quem and a geographical clue. We are provided with further, albeit less certain, biographical details in later traditions: Sedulius was a native of Rome, a layman or a cleric, who wrote his works in Greece after teaching in Italy, during the time when the reigns of Theodosius II and Valentinian III overlapped (425-450). ${ }^{6}$ Many of these details, to be sure, are found in manuscripts written centuries later and may have been constructed (on the basis of possible hints in the texts themselves) by medieval readers eager to assign responsibility for the composition of such well known works as the Paschale carmen or the hymn A solis ortus cardine to some kind of historical personage. But while the reliability of this later biographical material may be less secure, most of it is not necessarily in conflict with the actual historical evidence we possess (the fact of the Roman consul's "edition"), and it seems as perverse to ignore it as it would be to rely mindlessly upon it in making interpretative decisions.

What does Sedulius himself have to say about the poetic assignment he has set himself? He suggests that it is a fairly straightforward one, namely, to translate texts held sacred by Christians into the 'honeyed' language of verse. ${ }^{7}$ Sedulius' biblical epic fits into the long Roman tradition of taking works originally written in Greek and "translating" them into Latin. These "translations" are not mindlessly innovative, but neither do their authors seem to have felt overly constrained to be faithful to their "originals." Virgil and other Augustan poets try to improve on their Greek models as they write for their new, Latin-speaking, audiences. Something of the same kind of instinct may be said to animate the biblical poets of Late Antiquity. Certainly, their poems are not mere literary exercises. Juvencus, Proba, Sedulius, and others had loftier, more vatic, ambitions than schoolboys writing verse paraphrases as a

4 On the so-called "biographical fallacy" associated with critics such as Hippolyte Tain, and for a nuanced defense of such criticism, see Leon (1957).

5 See Green (2006) 142-3, on some of the questions raised by Asterius' "edition".

6 Both Aldhelm and Paschasius Radbertus claim a Roman provenance for Sedulius; Springer (2013) xvi. McDonald's suggestion that Sedulius must have been from the south of France (or northern Spain or Italy) was based on limited iconographic evidence and has since been 'adequately refuted'; Green (2006) 137-80. The idea that Sedulius was Irish is based on a confusion with his ninth-century namesake, Sedulius Scotus.

7 Ep. ad Mac. 1 (Springer [2013] 212). 
class assignment. ${ }^{8}$ Sedulius' stated aim is to retell the clara miracula Christi, which he does in four books, focusing on Jesus' miracles and life, while giving shorter shrift to his teachings (the first book of the Paschale carmen retells Old Testament miracles that might be seen as foreshadowing Jesus' own). His biblical epic, written in dactylic hexameters, is a direct challenge to the gentiles poetae (Paschale carmen 1.17), following the literary precedent set by Juvencus, who explicitly took on Homer and Virgil (see the preface to Evangeliorum libri, 9-10), whose own epic poems functioned as a sort of Bible for the ancient Greeks and Romans.

So, even though Sedulius adheres to the Christian Scriptures much more closely than Virgil does to Homer, the Paschale carmen does not simply reproduce one or all of the Gospels in another language and literary medium, despite what Sedulius himself may suggest about his fidelity to the four evangelists. Any reader of this poem who comes to it expecting to find a Gospel (or a harmony of the Gospels) fairly literally transposed into verse will quickly discover that Sedulius permits himself considerable poetic latitude as he versifies the words of the evangelists whom he apparently venerates (Paschale carmen 1.355-68). And this is why, by considering the ways in which Sedulius expands, abbreviates, ignores, or supplements these scriptural texts, we may reasonably hope to gain some sense of what he himself, whether consciously or unconsciously, intended his poem to be and to do. To fully appreciate that distinctiveness, of course, it is also important to situate Sedulius' poem within its own literary-traditional context and historical Sitz im Leben. How does his retelling of Gospel episodes compare with those of his poetic predecessors as well as earlier or contemporary biblical exegetes? How might his interpretations reflect the immediate perspectives and concerns of his own fifth-century contemporaries?

Nowhere in his descriptions of the characters who surround Jesus in the Paschale carmen may Sedulius' own distinctive poetic voice and ideological agenda be more discernible than in his representation of Peter, with the possible exception of Judas. ${ }^{9}$ Let us examine briefly an incident in the Paschale carmen (5.79-82 and 104-12) where Sedulius' depiction of the colorful fisherman turned disciple departs in significant ways from his canonical prototypes: Peter's denial of Jesus (Matt. 26.69-75; Mark 14.66-72; Luke 22.56-62;

8 The biblical epics of Late Antiquity received relatively scant scholarly attention until Reinhart Herzog's ground-breaking study in 1975, Die Bibelepik der lateinischen Spätantike. Since then there has been a steady increase of scholarship devoted to works such as Juvencus' Evangeliorum libri and Sedulius' Paschale carmen.

9 See Deerberg (2011). 
and John 18.25-7). Sedulius offers an explanation for Peter's disappointing performance under pressure that goes beyond anything suggested by the evangelists: when Jesus predicts that Peter will deny him, Sedulius explains that he does so not by way of rebuking him for lack of faith, but rather as a prediction that his disciple will be afraid: Non reprobando fidem, sed praedicendo timorem (Paschale carmen 5.82). Christ is not casting doubt on Peter's ultimate loyalty. Rather, Peter is going to suffer from an unavoidable, momentary lapse caused by an untypical bout of fear. Sedulius' Peter is otherwise largely unafraid, even when walking on the waves of Galilee. ${ }^{10}$ That Christ's prediction is one which Peter will have no choice but to fulfill can be gathered from the poet's parenthetical observation: 'since what Christ had said could not pass undone' (quoniam transire nequiuit / infectum quod Christus ait; Paschale carmen 5.105-6). Once Peter's divine Lord had predicted something, it would have to happen. It is almost as though Peter is a pawn in this particular set of circumstances; even if he had wanted to confess Jesus, it would have been impossible for him to do so after such an authoritative prophecy.11

Upon returning to his senses after the rooster's cries, Sedulius' Peter quickly repents of his act of denial, which, Sedulius says, he had committed mindlessly or even forgetfully (immemor). The poet clarifies this point in the Paschale opus, Sedulius' own prose paraphrase of the poem. Peter did not set out (non studuit) to deny Christ; his denial was the result of his being naïve and ignorant. It was really a case of forgetfulness (oblivionis). ${ }^{12}$ The kind of forgetting that Sedulius has in mind here is that of the man in James 1.24 who looks at his reflection in the mirror and upon going his way, immediately forgets (oblitus

10 In $P C$ 3.219-29, Sedulius describes Peter trying to walk on the Sea of Galilee with Jesus, without making any mention of the fact that, according to Matthew, Peter grew very afraid (validum timuit) and began to sink. Instead the poet emphasizes Peter's trust in Jesus and his uninterrupted (semper) acknowledgment of him as Christ. Our last view of Peter is as a confident pelagi viator gliding effortlessly 'over the glassy fields'. There is no hint of timidity here at all. In Matthew's account, by contrast, the episode ends with Jesus criticizing Peter's lack of faith (modicae fidei quare dubitasti), after Peter begs Jesus to save him from drowning. In Sedulius' recounting of the episode in the hymn $A$ solis ortus cardine, Peter, not Jesus, is the central focus of attention; see Homey (2013) 199-238.

11 Cyril of Alexandria (348-444) explicitly rejects such an interpretation: 'We do not say that the denial took place in order that Christ's words might come true. We say rather that his object was to forewarn the disciple ...' Commentary on Luke, Homily 149; transl. in Just (2003) 348. So does Chrysostom in Homily 82.3; transl. in Simonetti (2002) 252: 'Therefore Jesus resisted Peter, not compelling him to a future denial - God forbid! But he left him destitute of his help, convicting human nature'.

12 Igitur et Petrus apostolus Christum negare non studuit, sed in obliuionis casum simpliciter et ignoranter incurrit (Paschale opus 5.9; CSEL 10, 280). 
est) 'what manner of man he was.'13 In fact, it was his recollection of 'the magnificent example of his own faith' that prompted Peter's swift recovery. Peter recalled suddenly that he was the sort of man whom 'fear was unable to separate from Christ', not under any sort of threat of peril. After all, this was the same man whose faith had moved to hasten across the waters to join Christ, 'unmoved by any fear of death.1 ${ }^{14}$ It is only now, after the spell-binding prophecy has been fulfilled, that Peter is able to remember who he really was, the steadfast and fearless confessor of Christ. To be sure, his denial was still a transgression for which Peter had to be forgiven, but Sedulius goes to some lengths to offer his readers a sympathetic explanation of why one of the most important of his followers could possibly have denied Jesus at the moment of his Lord's greatest need. ${ }^{15}$

Among his contemporaries or near-contemporaries in Late Antiquity, Sedulius was not alone in his efforts to exculpate Peter, or at least diminish the extent of his fault. One ingenious interpretation, proffered by 'some people with a soft spot in their hearts for the apostle Peter', was that when Peter said: 'I do not know the man', he meant that he only recognized Jesus in his divinity, not his humanity. Jerome (347-420) calls such an interpretation 'frivolous' and points out that if true, it would mean that Jesus, who predicted the denial, was a liar. ${ }^{16}$ Juvencus, a contemporary of Constantine, one of the most

13 After his denial Peter remembered (recordatus est) Jesus' prediction (Matt. 26.75), but Sedulius seems to have a different kind of forgetting and remembering in mind here. On the relationship between sin and forgetting, see Trice (2011) 162. Chrysostom offers much the same explanation in Homily 85.1-2; transl. in Simonetti (2003) 269: 'And he was not even aware of his own lying. Luke says that Christ looked upon him, and this made it clear that he had denied him and was not even aware of how far he had fallen into forgetfulness'.

14 Nam qui sese mori uelle cum Domino plena deuotione promiserat, alienus ab eius uideri consortio sub quolibet periculo non ferebat. Prompserat enim inter cetera magnificum suae credulitatis exemplum, quod eum a Christo nec exitio posset segregare formido, ad quem media festinando per maria rapidos dudum se praecipitauit in fluctus, nulla uicinae mortis trepidatione deterritus (Paschale opus 5.9; CSEL 10, 280-1).

15 In PC 5.104 Sedulius calls him senior, a word which means literally "older" or "rather old", but most likely describes Peter's pride of place amongst the disciples (see Matt. 16.18-9) and not just his physical age. Proba uses the same adjective to describe Peter in her Cento (642-7), possibly, it has been suggested, in reference to the Quo vadis legend; see Dijkstra (2016) $116-7$.

16 'I know that some people with a soft spot in their hearts for the apostle Peter have interpreted this passage to the effect that Peter did not deny God but man, and what he meant was "I do not know the man, because I know God." The wise reader realizes how frivolous this interpretation is, for those who thus defend the apostle make the Lord guilty of a lie' (Jerome's Commentary on Matthew 4.26,72-75; transl. in Simonetti [2002] 269-70). Sedulius mentions Jerome in his first letter to Macedonius; see Springer (2013) 214. 
influential earlier poets whom Sedulius followed, praises Peter as praesolidus (1.422), stabilis (3.271), and fortis ( $3.273 ; 3.534) .{ }^{17}$ In Cathemerinon 1.57-64, another Christian Latin poet, Prudentius (348-c. 413), suggests that even though Peter was technically a negator, nonetheless he was iustus; even at the point of denial his 'mind remained innocent' (mens maneret innocens). ${ }^{18}$ In his Greek poetry, Gregory of Nazianzus (c. 329-390) depicts 'Peter more positively than in corresponding passages in the Bible.' ${ }^{19}$

Not all of Sedulius' contemporaries (or near-contemporaries) were as uncritical of the great apostle's failure. Cyril of Alexandria (376-444) spoke candidly of Peter's 'miserable act' which 'arose from the affliction of human cowardice.' ${ }^{20}$ John Chrysostom (c. 349-407) bluntly calls him a 'cringing denier' of Christ. ${ }^{21}$ Already in the fourth century, Eusebius of Caesarea (263-339) had recognized that the negative portrayal of Peter in the Gospels might actually serve to support their veracity, since why would propagandists for a cause include such incriminating details about one of their key founders if they were fabricating a purely made-up foundation mythology?22

So, why might Sedulius have wished to minimize Peter's failings? If Sedulius was a native of Rome, it would not be surprising for him to have a special

17 Dijkstra (2016) 90.

18 Dijkstra (2016) 208. There can be little doubt that Sedulius must have been influenced by Juvencus, if not Prudentius as well. See Costanza (1985).

19 Dijkstra (2016) 182. Sedulius does seem to be somewhat familiar with the Greek language $(P C$ 1.185-7) and mentions the work of Origen, the Greek theologian, in his second letter to Macedonius; see Springer (2013) 218. For a fuller discussion, see Springer (1988) 60-1.

$20 \quad$ Commentary on Luke, Homily 149; transl. in Just (2002) 349.

21 Homily 85.1; transl. in Oden and Hall (1998) 220. Augustine is especially severe: 'See how the pillar of greatest strength has at a single breath of air trembled to its foundations. Where now is all that boldness of the one who made promises and who had such overweening confidence in himself beforehand?... Is this the way to follow the Master - to deny his own discipleship? Is this the way one lays down his life for the Lord - frightened at a maidservant's voice that might compel us to the sacrifice'? (Tractates on the Gospel of John 113.2; transl. in Elowsky [2007] 277). Whether Sedulius actually read and responded to the works of earlier or contemporary Christian exegetes is difficult to determine. Where there are similarities of interpretation, the poet may have been influenced by oral traditions (e.g. sermons) or the written works of other theologians now lost, or he may have arrived at the same conclusions independently. Where there are differences, these, too, may be indirect or undeliberate.

22 Eusebius, Proof of the Gospel 3.5: 'Note how they [the disciples] handed down in writing numerous charges against themselves to unforgetting ages, and accusations of sins, which no one in later years would ever have known about unless hearing it from their own voice. By thus honestly reporting their own faults, it is reasonable to view them as relatively void of false speaking and egoism. This habit gives plain and clear proof of their truth-loving disposition'; transl. in Oden and Hall (1998) 220-1. 
interest in burnishing the image of the saint so closely associated with his own city. Even though his death is only hinted at in the vaguest of terms in the Gospel of John (21.19), there was a well known legend about Peter's death by crucifixion in Rome. According to this legend, as Peter was leaving the city of Rome to avoid arrest and certain death, he met Jesus going into the city. When he asked his Lord where he was going (Quo vadis?), Jesus responded that he was going into the city of Rome to be crucified. Rebuked, Peter came to himself, reversed his course, and returned to the city, where he ended up being crucified upside down. ${ }^{23}$ Along with Paul, Peter figured prominently in the ecclesiastical art of Rome in Late Antiquity (see Dresken-Weiland's and Löx's contributions to this volume), often depicted as flanking Jesus on either side, as they are in the mosaic in the apse of Santa Pudenziana (late fourth or early fifth century). Eventually his authority superseded that of Paul, at least in the Roman imagination. ${ }^{24} \mathrm{He}$ is the disciple upon whose testimony at least one of the evangelists (Mark) was thought closely to rely. He is the rock upon which Christ promised to build his church (Matt. 16.18). And he is the one whose see the bishop of Rome supposedly occupies. ${ }^{25}$

If Sedulius did live and write his poetry between 425 and $45^{\circ}$, he would have been a contemporary of Leo I (440-461), one of the most powerful of the early popes. In the late fourth and early fifth century, the bishopric of Rome was enhancing its prestige and extending its reach, and Leo played an important role in the process. ${ }^{26}$ The authority of the bishopric of Rome relied heavily on its association with the chief of the disciples, the apostle who holds the keys to the kingdom of heaven (Matt. 16.19). Leo was successful in expanding the claims of the bishopric far beyond the immediate city of Rome, based in part on its association with Peter. ${ }^{27}$ If, as has been argued, Sedulius' poem has a 'clearly anti-Nestorian theological agenda', it would make special sense to exalt

23 In the apocryphal Acts of Peter 35; ed. James (1924). The Chiesa del Domine Quo Vadis stands at the supposed spot today on the Appian Way.

24 On the connection between the apostle and the city in general, see O'Connor (1969).

25 Significantly enough for the poetic tradition, Peter plays an important role in a work heavily influenced by Sedulius, Arator's Historia Apostolica, a sixth-century biblical epic read aloud in Rome by its author, at the request of Pope Vigilius; see Deproost (1990). See Green (2006) 321, on the "virtual" assimilation of Peter and Vigilius in Arator's poem. Hillier (1993) devotes the first chapter of his book to the relationship between Arator and Vigilius.

26 On the growing emphasis on the 'fundamental Petrine doctrine' in the West, see Hornung (2015) 57. On the importance of Peter for Leo, see Moorhead (2015) 19-32.

27 The edict of Valentinian III (June 6, 445) was especially important in legitimizing the claims for the primacy of the bishop of Rome based upon its linkage with Peter; see Robinson (1905) 72. 
Peter, thought to be the episcopal predecessor of Leo at Rome. ${ }^{28}$ Leo's "Tome" played a crucial role at the crucial council of Chalcedon (451) as the bishops assembled there crafted a definitive response to Nestorianism. ${ }^{29}$

We may also be able to use internal evidence to shed light on how Sedulius might have expected his first readers to respond to his portrayal of Peter. It is essential, of course, to distinguish "audience" from "readers." In the first book of the poem (Paschale carmen 1.17-59), Sedulius seems to be addressing pagans (or half-hearted Christians) as he exhorts them to abandon the mendacia and figmenta of traditional pagan philosophy in favor of the truthful content of his scriptural poem (see also Paschale carmen 4.304). But it would be a mistake simply to take Sedulius "at his word" in this case, as some have recommended, and ignore other (and more likely) readers. ${ }^{30}$ The stated audience of a poem may be the product of an author's wishful thinking or, may indeed, be purely fictional. ${ }^{31}$ In fact, we know that Sedulius had specific Christians in mind as he was writing the poem. In his first prefatory epistle to the presbyter Macedonius he mentions some of them by name, e.g., Syncletica, a sacra virgo and ministra, Ursinus, an antistes, etc. ${ }^{32}$ These, along with Macedonius, are far more likely to have been his actual readers, and like Macedonius (to judge from the way in which Sedulius describes them), they were already well established Christians, and not pagans at all. ${ }^{33}$

Sedulius' account of the aftermath of Peter's denial may offer us a clue as to how he would have wanted Macedonius and others whose names he mentions in the letter to him to read this poem. After his resurrection, when Jesus appears to his disciples on the shores of Lake Tiberias and they have eaten breakfast, he proceeds to ask Peter three times whether he loves him. Each time Peter responds in the affirmative; each time Jesus tells him to feed his lambs (or sheep). The only Gospel account of this episode (John 21:15-19) does

28 Green (2006) 239-44.

29 When Leo's "Tome" was read at Chalcedon (October 8, 451), it was enthusiastically received by the bishops, who are said to have exclaimed: 'Peter has expressed this through Leo!' (Moorhead [2015] 27).

$30 \quad$ Mazzega (1996) 16.

$31 \quad$ Ong (1975) 405-27.

32 Springer (2013) 214-6. Sedulius refers to one of the members of Macedonius' circle as 'my Gallianus', suggesting a close personal relationship between them. On the "Romanness" of this and other names in Sedulius' first letter to Macedonius, see Green (2006) 140.

33 The conflict with paganism was not nearly so controversial in the fifth century as were theological controversies with heretics. Christological issues in particular were highly charged and divisive. Sedulius attacks the heresies of Sabellius and Arius by name in the first book of the Paschale carmen (1.299-325). 
not make the forgiveness of Peter explicit, but Sedulius leaves no doubt on that score:

... Then the shepherd who loves

to increase his sleek flocks, entrusted the sheep in every respct

to the good workman, and he entrusted his lambs to him too.

He gave him these admonitions three times, so that the recent offence of his triple denial might be removed by the same number.

Paschale carmen $5 \cdot 411-5$

This scene comes very near the end of Sedulius' poem. It is followed almost immediately (Paschale carmen $5.422-38$ ) by Jesus' final instructions to his disciples (cf. Matt. 28.18-20) and his departure from them into heaven (cf. Acts 1). This is an important moment in the process of transferring Jesus' own pastoral authority to his disciples. Jesus was already referred to by Sedulius as 'the good shepherd' (pastor ... bonus) early in the first book of this five-book poem (Paschale carmen 1.83). In the third, central, book of the Paschale carmen, Sedulius again refers to Jesus as the 'good shepherd'. ${ }^{34}$ These references to Jesus as shepherd, along with the description of him as pastor when he forgives Peter here near the end of the final book of the Paschale carmen, suggest that the idea of Jesus as a good shepherd is an important one to the poet. Why otherwise would it be repeated so often and at such important points in the poem? In the Gospels there is only one passage (John 10.11-16) in which Jesus calls himself 'the good shepherd'.

In the first instance in which Sedulius' Jesus is referred to as a good shepherd, the poet himself is praying for success with his poetic enterprise and asks for guidance on the path that leads to where the pastor bonus preserves his pleasant sheepfold. In Book 3, Sedulius is describing how Jesus commissions the disciples, including Peter, to go out to minister to his greges. He is himself the pastor bonus (Paschale carmen 3.167-8). In the final reference to Jesus as shepherd in book 5 , however, Sedulius transfers the adjective. Here Jesus is referred to as 'the shepherd who loves', not 'the good shepherd', even though it is Peter who has been affirming repeatedly that he is the one who loves Jesus. But now it seems that Jesus loves, too. And then, significantly, Sedulius goes on

34 The word pastor occurs in the central line, the 167 th of the 333 lines in this central book of the poem. In the middle of the fourth book (154) the 72 disciples whom Jesus sends out are described as sheep. Roughly in the middle of the fifth book (220), Sedulius describes Jesus as the shepherd who gathers in his sheep to his heavenly sheepfold; see Mazzega, Sedulius, 169 . 
to describe as bonus the disciple whom Jesus is singling out here to carry on his pastoral work. On the verge of his ascension to heaven, the shepherd 'who loves to increase his flocks' is making Peter a good shepherd, too, to serve as pastor to his flock in his own stead.

The good shepherd had become a veritable iconographic fixture in Christian churches and catacombs by the first half of the fifth century (although it was to disappear soon thereafter). ${ }^{35}$ The sheep-tending and feeding metaphor is a venerable one (see, e.g., Acts 20.28-9), and over time it became inextricably associated with clerical functions. In his first prefatory letter to him, Sedulius describes Macedonius himself as a shepherd: 'for some you became a role model for salvation; on seeing others you made them sheep in the fold of your flock; others you fed.... ${ }^{36} \mathrm{He}$ is not simply Sedulius' literary patron. Nor are those around him part of a literary circle only. This is a flock of believers, tended and fed by a spiritual shepherd who derives his own authority from Jesus through Peter. The bond of Christian faith connects this congregation to each other and to their immediate spiritual leader, Macedonius, the presybter, linking them to Peter and ultimately to Jesus himself, who is the 'chief shepherd' of 'the flock of God' (1 Peter 5.2-4). As he makes clear in his letter, Sedulius sees himself as a member (or potential member) of this particular flock, craving the pastoring of Macedonius. At the same time he is himself a shepherd of sorts, too, who aims to feed his readers with the Gospel. ${ }^{37}$ Sedulius' Paschal Song is food, as he suggests in the preface (the Eucharistic connotations are hard to miss), because its subject is Christ, the paschal lamb, who takes away the sins of Peter and Macedonius and Sedulius. Just as food nourishes the body, so Sedulius' spiritual food, his paschal feast, may have been meant, most immediately, to strengthen the links that connected the body of Christ that had assembled itself around its Petrine pastor, Macedonius. ${ }^{38}$

Did Sedulius himself really come from Rome? Was he really interested in enhancing the prestige of the apostle upon whom the bishop of Rome depended for his authority? Did he really intend for Macedonius and his flock to read this poem as we have suggested? These questions may never be answered definitively. What we do know for certain, however, is that some medieval readers thought that Sedulius came from Rome and was a contemporary of Pope Leo. We also know that of the poets of Late Antiquity, Sedulius was among the most

35 Ramsey (1983) $375^{-8 .}$

36 Springer (2013) 216.

37 Hence, perhaps, the confusion in the later tradition as to whether Sedulius was a layman or a cleric.

38 Jesus himself is not only shepherd but sheep, the lamb of God who is sacrificed for the sins of the world (PC 2.148-9 and 5.356). 
popular throughout the Latin Middle Ages. Regardless of how Sedulius may have hoped that his poetic effort would be received by Macedonius and his congregation (or how it actually was received when published in Rome in the late fifth century), it is hard to imagine that the poet would have been disappointed had he known how widely circulated this poem, set in Palestine, was eventually to become over so many subsequent centuries among so many other flocks of Catholic Christian believers (and their pastors), wherever they may have been in Western Europe, "anchored" to the apostle whom they believed to be the first bishop of Rome. ${ }^{39}$

\section{Bibliography}

Constanza, S. 1985. Da Giovenco a Sedulio. I proemi degli Evangeliorum libri e del Carmen paschale. Civiltà classica e cristiana 6:235-86.

Curtius, E. 1973. European Literature and the Latin Middle Ages. Princeton: Princeton University Press.

Deerberg, D. 2011. Der Sturz des Judas: Kommentar (5.1-163) und Studien zur poetischen Erbauung bei Sedulius. Münster: Aschendorff.

Deproost, P. 1990. L'apôtre Pierre dans une épopée du VIe siècle: L'Historia apostolica d'Arator. Paris: Études Augustiniennes.

Dijkstra, R. 2016. The Apostles in Early Christian Art and Poetry. Leiden: Brill.

Elowsky J. 2007. Ancient Christian Commentary on Scripture: New Testament IVb John 11-21. Downers Grove: Invervarsity Press.

Farrell, J. 2017. Varieties of Authorial Intention: Literary Theory Beyond the Intentional Fallacy. Cham: Palgrave-MacMillan.

Green, R. 2006. Latin Epics of the New Testament. Oxford: Oxford University Press.

Herzog, R. 1975. Die Bibelepik der lateinischen Spätantike. Formgeschichte einer erbaulichen Gattung I. Munich: Fink.

Hillier, R. 1993. Arator and the Acts of the Apostles: A Baptismal Commentary. Oxford: Clarendon Press.

Homey, H. 2013. Christus fluenta tangit: Sedulius, carm. pasch. 2, 137-174; 3, 46-69; 219235. Wiener Studien 126: 199-238.

Hornung, C. 2015. Siricius and the Rise of the Papacy. In The Bishop of Rome in Late Antiquity, ed. G. D. Dunn, 56-72. Ashgate: Farnham/Burlington.

39 On the continued popularity of the poem up into the early modern period and the wide distribution of manuscripts across Western Europe, see Springer (1995) 5-6. In the Paschale opus (CSEL 10, 191), Sedulius cites Virgil's reference to Rome in Ecl. 1.26-7, as he contrasts the heavenly Jerusalem with earthly cities. 
James, M. 1924. The Apocryphal New Testament. Oxford: Clarendon Press.

Just, A. 2003. Ancient Christian Commentary on Scripture: New Testament III Luke. Downers Grove: Intervarsity Press.

Leon, E. 1957. Literary Biography. Toronto: University of Toronto Press.

Mazzega, M. 1996. Sedulius, Carmen Paschale, Buch III. Ein Kommentar. Basel: Schwabe. McDonald, A. 1933. The Iconographic Tradition of Sedulius. Speculum 8: 150-6.

Moorhead, J. 2015. The Pope and the Church of Rome in Late Antiquity. London: Routledge.

O'Connor, D. 1969. Peter in Rome: The Literary, Liturgical, and Archaeological Evidence. New York: Columbia University Press.

Oden, T. \& C. Hall. Ancient Christian Commentary on Scripture: New Testament II Mark Downers Grove: Intervarsity Press.

Ong, W. 1975. The Writer's Audience is Always a Fiction. Proceedings of the Modern Language Association 90: 405-27.

Ramsey, B. 1983. A Note on the Disappearance of the Good Shepherd from Early Christian Art. Harvard Theological Review 78: 375-8.

Robinson, J. 1905. Readings in European History. Boston: Ginn.

Simonetti, M. 2002. Ancient Christian Commentary on Scripture: New Testament Ib Matthew 14-28. Downers Grove: Intervarsity Press.

Springer, C. 1988. The Gospel as Epic in Late Antiquity: The Paschale carmen of Sedulius. Leiden: Brill.

Springer, C. 1995. The Manuscripts of Sedulius: A Provisional Handlist. Philadelphia: American Philosophical Society.

Springer, C. 2013. Sedulius, The Paschal Song and Hymns. Atlanta: Society of Biblical Literature.

Trice, M. 2011. Encountering Cruelty: The Fracture of the Human Heart. Leiden: Brill. 